DOI: https://doi.org/10.47405/mjssh.v6i12.1198

\begin{tabular}{|c|c|}
\hline & Malaysian Journal of Social Sciences and Humanities (MJSSH) \\
\hline Malaysian Journal of & Volume 6, Issue 12, December 2021 \\
\hline (MJ-SSH) & e-ISSN : 2504-8562 \\
\hline & $\begin{array}{l}\text { Journal home page: } \\
\text { www.msocialsciences.com }\end{array}$ \\
\hline
\end{tabular}

\title{
Kesan Elitisme dan Pluralisme dalam Politik Malaysia
}

\author{
Izairuddin Isnin'1, Jamaie Haji Hamil'1, Muhamad Nadzri Mohamed Noor ${ }^{1}$ \\ 1Program Sains Politik, Pusat Kajian Sejarah, Politik dan Hal Ehwal Antarabangsa, \\ Fakulti Sains Sosial dan Kemanusiaan, Universiti Kebangsaan Malaysia (UKM), Malaysia
}

Correspondence: Jamaie Haji Hamil (email-jamaie@ukm.edu.my)

\begin{abstract}
Abstrak
Ketahanan UMNO dalam politik Malaysia sering dikaitkan dengan penerusan amalan tradisionalisme politik yang umumnya dirujuk sebagai neo-feudalisme. Dalam wacana teoritikal demokrasi, amalan ini boleh ditakrifkan sebagai elitisme di mana aktor-aktor utamanya terdiri daripada golongan berada, dengan politik hierarki serta dengan praktik penaungan dan politik identiti. Namun amalan ini dicabar hebat oleh golongan kelas menengah dan pekerja khasnya di kawasan-kawasan urban, dengan politik progresivisime, berakar umbikan dengan gerakan sivil sejak lewat 1990an. Politik yang lebih terpencar ini, ditakrifkan sebagai politik pluralisme mendapat momentum sehinggakan UMNO dan koalisinya Barisan Nasional ditumbangkan pada Pilihan Raya Umum ke-14 (PRU-14). Tulisan ini secara bersederhana, bertujuan untuk menyusurgalurkan dan meneroka pertembungan politik elitisme dan pluralisme di Malaysia. Mengguna pakai kaedah temu bual separa berstruktur dalam melengkapkan kajian kepustakaan, kajian ini menghujahkan ketahanan elitisme di sebalik transformasi politik yang lebih pluralistik kini, di sebalik transisi dan ketidakstabilan politik di Malaysia lewat ini.
\end{abstract}

Kata kunci: Barisan Nasional, elitis, pluralis, politik, kelemahan pentadbiran

\section{The Effects of Elitism and Pluralism in Malaysia Politics}

\begin{abstract}
UMNO's resilience in Malaysian politics is often associated with the continuation of the practice of political traditionalism which is generally referred to as neo-feudalism. In the theoretical discourse of democracy, this practice can be defined as elitism in which the main actors are composed of the wealthy, with hierarchical politics as well as with the practice of patronage and identity politics. Yet this practice is fiercely challenged by the middle class and workers especially in urban areas, with the politics of progressivism, rooted in the civil movement since the late 1990s. This more fragmented politics, defined as the politics of pluralism gained momentum until UMNO and its Barisan Nasional coalition were overthrown in the 14th General Election (GE-14). Using a semi-structured interview method in completing the literature review, this study argues for the resilience of elitism despite the more pluralistic political transformation now, despite the recent transition and political instability in Malaysia.
\end{abstract}

Keywords: Barisan Nasional, elitist, pluralist, political, administrative weaknesses 


\section{Pengenalan}

Malaysia merupakan sebuah negara multi-etnik yang berjaya menguruskan konflik antara kaum dengan baik. Etnik Melayu merupakan majoriti diikuti oleh Cina, India dan lain-lain. Hasrat kerajaan ialah untuk menyatukan semua etnik di bawah satu payung yang dikenali sebagai Bangsa Malaysia. Apa yang dihasratkan melalui Bangsa Malaysia ialah setiap individu akan mempunyai rasa kesepunyaan sebagai satu bangsa dalam sebuah negara iaitu Bangsa Malaysia dengan tidak meletakkan identiti diri mengikut ras. Jadi Bangsa Malaysia merupakan konsep yang mewakili semua ras yang ada di Malaysia di bawah satu payung bangsa. Bagaimanapun, politik Malaysia kini sedang menghadapi cabaran perpaduan yang meruncing terutama politik Melayu. Pergolakan dalam politik Melayu dikesan semakin parah selepas pilihan raya umum 2008.

Sebanyak lima buah negeri yang dikuasai oleh parti pemerintah iaitu Barisan Nasional (BN) terdiri daripada gabungan tiga parti terbesar mewakili etnik Melayu, Cina dan India seperti UMNO (United Malay National Organization), MCA (Malaysia Chinese Association), MIC (Malaysian Indian Congress) dan parti-parti di Sabah dan Sarawak yang mewakili kaum di sana telah jatuh ke tangan pembangkang. UMNO yang merupakan parti terbesar orang Melayu hilang banyak kerusi Parlimen dan Dewan Undangan Negeri (DUN). Ramai orang Melayu yang menyokong UMNO berpihak kepada pembangkang. Kedudukan UMNO sebagai parti terkuat orang Melayu semakin tergugat (Suhana, 2012). Di samping itu, parti Melayu lain dalam pembangkang atau dikenali sebagai Pakatan Rakyat (PR) yang terdiri daripada PAS (Pan-Malaysia Islamic Party), PKR (Parti Keadilan Rakyat) juga mengalami krisis perpecahan dan kepimpinan yang meruncing. Dalam PR juga terdapat DAP (Democratic Action Party) yang multi-etnik tetapi majoriti ahlinya adalah Cina. Persoalannya sejauh mana pertembungan politik elitisme dan pluralisme berlaku di Malaysia. Ianya dilihat daripada dua sudut iaitu mengenal pasti perspektif elitis di dalam memerihalkan kejatuhan Kerajaan Barisan Nasional dan mengenal pasti perspektif pluralis di dalam memerihalkan kejatuhan Kerajaan Barisan Nasional. Setakat ini banyak kajian yang memberi fokus kepada peranan Barisan Nasional di dalam mempertahankan kuasa, namun belum ada lagi analisis yang dilakukan berkaitan dengan tumpuan sifat elitis dalam Barisan Nasional dan peranan politik yang lebih pluralis menentang mereka dari memegang tampuk kuasa sehingga rebah pada PRU ke-14.

\section{Metod Kajian}

Kaedah temu bual separa berstruktur akan dilaksanakan sebagai data primer. Ini bertujuan untuk memperoleh maklumat daripada setiap kumpulan informan dengan lebih bersahaja, dan juga untuk mengelakkan informan berasa tertekan dengan soalan-soalan yang diajukan kelak. Kajian kepustakaan pula dijadikan sandaran sebagai data sekunder bagi memperkukuhkan dapatan kajian. Bagi tujuan persampelan, pemilihan sampel adalah secara pemilihan bertujuan kepada pemegang taruh (purposive sampling). Teknik ini adalah sesuai berdasarkan ketokohan informan di dalam bidang masing-masing bagi melihat dari pelbagai dimensi dan perspektif.

\section{Kajian Lepas}

\section{Kesan Elitis Politik Malaysia}

Terdapat kajian yang pernah dijalankan berkaitan dengan isu politik iaitu Mujibu et al. (2020) mengkaji perubahan politik di Malaysia. Sementara itu kajian Muhamad Nadzri dan Jamaie (2018) mengetengahkan isu berkaitan dengan politik, pengundi dan faktor Melayu dan Suhana et al. (2012) mengkaji krisis politik Melayu. Kajian mereka juga menyentuh tentang elitis dan pluralis politik Malaysia. Selain itu, kajian Masshelayati (2020) mengkaji masyarakat dan politik dari sudut tinjauan tingkas menyatakan salah satu aspek yang membentuk budaya politik mereka dan masyarakat yang memperlihatkan dunia politik yang boleh meramal dengan mengambil bahagian dalam politik. Menurut Agus (2020) pula politik elitis berakar pada masalah kemanusiaan dan sekali gus pada keuntungan ekonomi. Politik menuntut bangsa supaya ke arah kemajuan, namun politik tetap akan bernaung. 
Dalam pengertian umum, elit merujuk kepada sekumpulan orang yang wujud dalam masyarakat dan berkedudukan yang tinggi. Pengertian khusus, elit adalah kelompok orang yang terkemuka di dalam bidang-bidang yang tertentu serta golongan minoriti yang memegang kekuasaan. Keller (1995), elit merupakan individu di dalam sebuah kelompok masyarakat yang memiliki pengaruh dan peranan yang kuat. Elit adalah individu-individu yang efektif dan bertanggungjawab yang fokus kepada pelaksanaan, kegiatan, kepentingan dan perhatian kepada orang lain seperti mana yang diistilahkan oleh Bottomore (2006).

Elit politik yang muncul di dalam bidang sosiologi adalah untuk membezakan satu komuniti dengan komuniti yang lain. Dalam konteks penyelidikan politik, elit politik diterjemahkan kepada makna keperluan untuk kestabilan dan kemakmuran. Kajian Haryato (2009) menyatakan bahawa elit politik sangat mempengaruhi pembatasan (constraining) dari struktur (structure). Elit diterjemahkan sebagai kuasa pengaruh individu di dalam sebuah masyarakat yang paling berbakat seperti elit organisasi, elit agama, elit pakar, elit organisasi dan lain-lain. Dari segi perspektif sosiologi, elit lebih menjurus kepada elit politik. Kajian mengenai elit telah banyak dijalankan oleh sarjana dan tokoh sejak perkembangan pemerintahan dunia. Menurut Lasswell dan Lerner ( 1952 ) iaitu:

"Government is always government by the few, whether in the name of the few, the one or the many",

(Lasswell \& Lerner, 1952 )

Demokrasi adalah pemerintahan oleh banyak orang, tetapi dalam praktiknya demokrasi bergantung kepada kelompok kecil orang dalam menjalankannya, inilah yang disebut dengan Ironi Demokrasi. Ciriciri politik baru ini secara perlahan mengikis amalan politik lama yang selama ini dipupuk oleh parti pemerintah dalam mengekalkan kuasa (Mujibu et al., 2020). Dominasi BN dalam politik Malaysia selama ini berkait rapat dengan amalan politik perkauman, permuafakatan, pecah dan perintah, pengawalan dan pembangunan (Badrul, 2008). Elit dalam konteks ilmu politik menunjukkan kelompok kecil orang yang memiliki kekuasaan, sebaliknya massa adalah elemen terbesar yang tidak memiliki kekuasaan.

Asasnya, sesebuah negara untuk digelar sebagai negara demokrasi harus menonjolkan tujuh ciri-ciri utama; pertama, wujudnya kebebasan bersuara, media massa yang bebas dan berkecuali, pilihan raya diadakan secara konsisten, bebas dan adil, ada kebebasan berorganisasi dan berpersatuan, pemerintahan berasaskan majoriti, hak golongan minoriti dihormati dan akhir sekali wujud badan kehakiman yang senantiasa bebas dan berkecuali (Zaini, 2006). Pembahagian masyarakat ke dalam elit dan massa bersifat universal. Konsep elit, tidak dibentuk atau dilahirkan oleh sosialisme atau kapitalisme, sistem represif atau demokratik, agrikultur atau industri, tetapi semua masyarakat memerlukan elit.

Pandangan awal yang dikemukakan oleh sarjana klasik seperti Pareto, Mosca dan Michel. Pengkaji akan menelusuri rujukan mengenai perbahasan elit dan elit politik berdasarkan rujukan dan hujah oleh Bottomore (1996). Pandangan sarjana tersebut telah meneroka dan memberi pandangan dengan perbahasan mengenai hujahan elit dan elit politik yang akan diterangkan sebagai menelusuri penghujahan pelopor klasik.

Elit adalah merupakan individu-individu yang berjaya menjawat jawatan tinggi dalam kalangan masyarakat. Elit dibahagikan kepada dua kelas iaitu kelas pertama: elit yang memerintah (governing elite) bermaksud individu-individu secara langsung atau tidak langsung memainkan peranan yang besar dalam pemerintahan. Kedua iaitu elit yang tidak memerintah (non-governing elite). Kelas yang kedua ialah lapisan rendah (non-elite) Maka dapat dirumuskan bahawa masyarakat mempunyai dua lapisan iaitu lapisan rendah dan lapisan tinggi yang terpisah kepada dua iaitu elit yang memerintah dan elit yang tidak diperintah. Menurut Bottomore (1996), penghujahan Vilfredo Pareto (1848-1923) istilah elit untuk menjelaskan bahawa ketidaksetaraan kualiti individu di dalam setiap ruang lingkup kehidupan sosial. Setiap masyarakat diperintah oleh sekelompok kecil individu yang mempunyai kualiti yang diperlukan bagi kehidupan mereka pada kekuasaan politik dan sosial yang menyeluruh. 
Menurut Bottomore (1996), penghujahan Gaetano Mosca (1858-1941) mengatakan elit secara kebiasaannya muncul kepada dua kelas di dalam sesebuah masyarakat. Dua kelas itu adalah kelas yang berkuasa dan kelas yang dikuasai. Kelas yang menguasai jumlahnya lebih sedikit, melaksanakan semua fungsi politik, memonopoli kekuasaan, dan menikmati keistimewaan. Manakala kelas yang dikuasai jumlahnya lebih banyak, diperintah, dan dikendalikan oleh kelas yang memerintah dengan cara yang berlandaskan peraturan pemerintahan dan kejam. Perwatakan individu elit dapat dibezakan melalui gaya komunikasi untuk memimpin dan melaksanakan kawalan politik.

Lipset dan Solari dalam Scoorl (1982) elit adalah mereka yang menempatkan posisi di dalam masyarakat di puncak struktur-struktur sosial yang terpenting iaitu posisi tinggi di dalam ekonomi pemerintahan, ketenteraan, politik, agama, pendidikan dan lain-lain. Field dan Higley dalam Kuper (2000) secara sederhana menyatakan bahawa elit adalah orang-orang yang memiliki posisi strategik, yang secara awam dipandang sebagai sebuah kelompok. Merekalah yang membuat keputusan umum, yang satu sama lain melakukan koordinasi untuk menonjolkan peranannya. Dengan rumusan pemahaman yang sederhana oleh pengkaji, makalah penghujahan yang dibahaskan oleh sarjana-sarjana yang disoroti menunjukkan bahawa elit mempunyai kedudukan yang tinggi dan memerintah kepada masyarakat yang lebih ramai bilangannya, mempunyai daya pengaruh yang tinggi terhadap bawahannya, individu yang membuat keputusan politik di dalam institusi politik dan sebagai simbol pemimpin kepada ahli-ahlinya. Merujuk kepada ulasan pengkaji, sarjana yang membahaskan mengenai elit dan elit politik masih tidak menyentuh dan mampu mengancam teori yang berkaitan dengan demokrasi. Mereka hanya menyentuh dan membahaskan kerangka konsep dan pelbagai ideologi. Maka ini jelaslah pelbagai perbahasan yang membawa maksud yang hampir serupa iaitu elit sebagai kelas penguasa yang secara efektif memonopoli kedudukan-kedudukan penting di dalam masyarakat

Hakikatnya, peranan ahli politik semakin diberi perhatian dan dianggap penting bukan sahaja di Malaysia tetapi di seluruh dunia. Malahan, Commonwealth Heads of Government Meeting (CHOGM) pada tahun 2002 dengan jelas menyebut tentang pentingnya peranan yang dimainkan oleh politik kepada masa depan di seluruh dunia. Para pemimpin negara Komanwel ini mengakui tentang kepentingan penglibatan golongan politik dalam proses pembentukan negara bangsa (Ramli et al., 2018).

Dalam kalangan belia, protes kepada BN amat ketara. Kegagalan BN menangani masalah-masalah yang berkait dengan kepentingan dan kelangsungan belia menyebabkan kumpulan ini mula kritikal dan menunjukkan protes dan rasa tidak senang kepada pihak pemerintah. Keadaan lebih buruk berlaku kepada kumpulan yang baharu tamat pengajian di institusi pengajian tinggi kerana mereka amat terkesan dengan landskap sosioekonomi dan politik negara. Isu kenaikan harga barang, isu PTPTN, ketiadaan kerja, pembuangan kerja dan sebagainya mempengaruhi persepsi negatif mereka kepada BN yang dilihat gagal mentadbir negara dengan baik. Rasa tidak senang dan protes ini turut dibawa ke rumah dan mereka berterusan mendesak ibu bapa dan ahli keluarga untuk mengundi selain daripada BN. Dalam kalangan belia, kemarahan ini diterjemahkan dalam bentuk undi ke atas parti selain BN. Berbeza dengan beberapa PRU lepas, pada PRU-14, isu ini dilihat lebih mencabar kerana peranan media massa dan media elektronik yang 'menipiskan' lapisan antara kampung dan bandar yang akhirnya membawa perubahan besar kepada para pengundi, terutamanya kumpulan belia. Arshad, salah seorang responden yang diajukan soalan tentang isu GST dan bagaimana ia memberi kesan kepada kehidupan belia menyatakan;

$$
\begin{aligned}
& \text { krisis ekonomi 1998, kerajaan tidak kacau rakyat...sekarang GST sangat } \\
& \text { membebankan rakyat... harga barang semua naik ... dari lahir (lampin anak) } \\
& \text { sampai ke mati (kain kafan) semua barang naik... }
\end{aligned}
$$

(Arshad, 27 April 2018)

Kajian ini mendapati bahawa peranan politik amat bermakna dengan ciri-ciri kepimpinan yang sering kali dilakukan dan memainkan peranan yang penting dalam PRU-14 kerana mereka menjadi penyumbang kepada kekalahan Barisan Nasional (BN). Oleh itu, kajian ini turut mendapati bahawa kumpulan belia yang mewakili hampir separuh daripada jumlah pengundi di Parlimen tersebut 
merupakan cabaran besar kepada parti pemerintah pada masa akan datang sekiranya isu berkait ini tidak ditangani dengan baik.

\section{Kesan Pluralis dalam Politik Malaysia}

Pada perspektif ini pengkaji menggambarkan amalan elit politik di dalam mempertahankan sesebuah kekuasaan seakan dicabar dengan kelompok politik plural yang kian terpancar dalam pertumbuhan demokrasi yang lebih baik. Pengenalan istilah akan dibahaskan termasuk istilah daripada sarjana yang berkenaan dan penerokaan bagaimana politik plural dibentuk dalam proses pendemokrasian di dalam sesebuah negara.

Pluralisme adalah satu fahaman atau teori yang menganggap bahawa realiti itu terdiri dari banyak komponen. Pluralisme politik telah membuat trend pemikiran baru. Trend tersebut kemudian berpengaruh pada ranah sosial lain seperti pluralisme agama dan pluralisme etnis (Mohd Taufik et al., 2019). Dari sudut pandangan lain, pluralisme iaitu " ketulusan hati " pada diri setiap manusia untuk menerima keanekaragaman yang ada. Kesan daripada pluralisme turut melindungi kesetaraan dan menumbuhkan rasa persaudaraan di antara manusia sebagai individu mahu pun kelompok. Pluralisme juga memberi peluang untuk menuntut upaya untuk memahami pihak lain dan kerjasama mencapai kebaikan bersama ia juga boleh diterjemahkan sebagai semua manusia dapat menikmati hak dan kewajipannya setara dengan manusia lain (DA, Nurfasitasari, 2014). Istilah demokrasi pluralis sebagai "pemerintahan orang yang banyak" dan hal tersebut ditafsirkan sebagai pemerintah yang beroperasi atas dasar kepentingan-kepentingan setiap warga. Kelompok minoriti pula, kesan daripada pluralisme ini menunjukkan bahawa masyarakat boleh mewujudkan satu peranan kelompok majoriti (Pue \& Charanjit, 2014).

Pemahaman mengenai pluralis juga dijelaskan dengan menerima perbezaan yang wujud di antara manusia dengan manusia yang lain juga dapat difahami sebagai pluralisme (Adzib, 2015). Masyarakat pluralistik yang terdiri daripada lebih 70 kumpulan etnik dengan adat resam, nilai dan kepercayaan, bahasa dan agama yang berbeza, soal etnisiti berada di tampuk teratas dalam senarai sembilan kontradiksi yang harus diselesaikan sebelum Malaysia dapat mencapai perpaduan yang diidamkan (Shamsul, 2014). Miles dan Brown (2003) serta Holst (2012) pula melihat setiap kumpulan etnik sebagai menggunakan kesedaran etnik yang disemai dari generasi ke generasi melalui proses ethnicization untuk bergerak sebagai satu kolektif dalam persaingan dengan kumpulan-kumpulan etnik lain untuk memenuhi keperluan masing-masing.

\section{Kedudukan Politik Elitisme di Malaysia}

Haikal (2011) dalam kajiannya mengenai pemikiran Niccolo Machiavelli atas etika dan kekuasaan dalam rencah politik. Situasi sosial dan politik yang belum stabil menuntut seseorang pemimpin untuk melakukan berbagai upaya untuk mengekalkan kekuasaan, tambahan pula kekuasaan politik terletak pada kepimpinan Presiden UMNO. Jamaie (2003) menyatakan bahawa pola kepimpinan politik Melayu khususnya UMNO adalah merupakan sistem politik yang sangat stabil dan ianya bergantung kepada keupayaan pemimpin yang mempunyai autoriti untuk melaksana tanggungjawab di dalam menangani sebarang konflik. Penggunaan kerangka konseptual kepimpinan politik, kajian ini mendapati wujud dinamisme pola kepimpinan.

Kestabilan politik hanya akan mengundang kepada keadaan yang tidak menentu bagi sesebuah negara. Nilai dan etika yang paling tinggi adalah negara yang bijak yang disebut virtu, stabil dan tindakan yang dilakukan oleh pemimpin adalah untuk melindungi sesebuah negara yang ditadbir sehingga dia membenarkan tindakan kejam seseorang pemimpin semasa pemerintahan dan berusaha untuk tidak dibenci. Hal ini melibatkan perkauman antara rakyat Malaysia. Wacana mengenai etnisiti di Malaysia sama ada dalam ruang akademik mahupun media massa hari ini adalah cenderung berkisar kepada tiga kategori etnik utama iaitu Melayu, Cina dan India (Pue \& Charanjit, 2014).

Wade (2014) menyatakan tentang elitis ini adalah satu paradigma politik perkauman yang dibentuk melalui kerangka "pecah dan perintah" oleh kolonial dan ianya memberi kesan sehingga ke hari ini. 
Maka konsep politik permuafakatan dibentuk ketika Malaya ingin mencapai kemerdekaan daripada kuasa jajahan British yang membentuk struktur landskap politik berasaskan kaum di Malaysia hasil konsensus tiga parti utama iaitu UMNO, MCA dan MIC.

Akta Hasutan yang pada awalnya dilaksanakan sebagai menjaga kesejahteraan pelbagai kaum dan menghalang daripada kelakuan atau tindakan yang dikira sebagai mewujudkan perasaan tidak setia kepada raja-raja atau pemerintah. Namun, akta ini terarah kepada menjaga kepentingan politik parti pemerintah. Jesudason (1996), berhujah terdapat percanggahan idea tentang demokrasi yang diamalkan oleh rejim Barisan Nasional (BN) di mana ianya dianggap statik dan wujud pelbagai kawalan rakyat tidak menikmati kebebasan yang penuh daripada penghayatan Akta Hasutan, ISA dan akta-akta yang lain yang bersifat kawalan. Crouch (1996:82-84) menjelaskan tentang beberapa akta yang bersifat kawalan di Malaysia.

\section{Kedudukan Politik Pluralisme di Malaysia}

Bachrach dan Baratz (1977) yang menolak kuasa berpolitik hanya untuk golongan elit dan memecahkan kumpulan politik kepada dua bentuk iaitu kumpulan elitis dan pluralis. Golongan elitis adalah pihak pemerintah yang berkuasa dalam membuat dasar-dasar atau polisi kerajaan manakala golongan pluralis memegang kuasa dengan memperjuangkan isu-isu yang berkaitan dengan rakyat dan masyarakat. Pendekatan ini boleh digunakan bagi memahami perkaitan politik Barisan Nasional (BN) yang didominasi oleh UMNO mengekalkan dominasi dan pengaruh elitis dengan parti gabungan yang ada di dalam Barisan Nasional (BN).

Mazlan et al. (2012) telah menyentuh mengenai perkembangan politik selama tiga dekad yang mengatakan bahawa PRU 1969 menjadi titik penentu pada perubahan landskap politik di Kuala Lumpur di mana memotivasikan pemerintah politik untuk melakukan perubahan dengan menyusun semula ekonomi dan masyarakat melalui Dasar Ekonomi Baru (DEB) pada sekitar 1971. Majid (2010), pluralisme merupakan satu episod dari elemen demokrasi. Ianya dapat difahami sebagai bentuk keterlibatan aktif keragaman dan perbezaan dengan berobjektif membangun peradaban bersama untuk mencapai tujuan sosial yang lebih tinggi iaitu kebersamaan dalam membangunkan peradaban. Karppinen (2007), pluralisme ini adalah satu cabang yang melihat kepada sesuatu perkara yang pelbagai kepada satu aspek dan kepelbagaian itu juga hendaklah lebih seragam sifatnya. Flathman (2007), salah satu nilai pluralistik politik ialah mengekal dan mencipta persaingan dan konflik di mana dengan sendirinya mengekal daripada keadaan dominasi dan hegemoni.

Dasar ini juga dilihat membawa kepada perubahan kepada landskap politik Kuala Lumpur kesan daripada cetusan pluralisme. Berdasarkan elemen politik ini yang menjadi satu dimensi untuk dibahaskan dan dibincangkan topik ini, pengkaji membuat pemerhatian secara mendalam dengan mengambil beberapa hasil dapatan yang relevan terhadap pendemokrasian di Malaysia dalam konteks elit, kelas dan pluralisme.

\section{Istilah Pluralisme dari Pandangan Sarjana}

Santrock (2003), pluralisme adalah penerimaan setiap individu yang berpandangan bahawa perbezaan budaya harus sentiasa dipertahankan dan dihargai. Pluralisme telah pun banyak dibincangkan melalui 3 perspektif iaitu dari aspek falsafah, agama dan sosiolosi. Menurut Nilai penghormatan itu dijelmakan dalam bentuk sikap yang saling menghormati dan menghargai yang merupakan tiang seri dalam pembentukan pluralisme. Pengertian pluralisme juga adalah pandangan falsafah yang menggambarkan semua prinsip atau keyakinan peribadi dan bersedia menerima perbezaan kepelbagaian yang lain termasuk dari segi dimensi agama, budaya dan juga politik seperti yang dibahaskan oleh Collins dan Farrugia (1996). Pluralisme adalah banyak atau tidak satu seperti aneka budaya di dalam masyarakat (Moeliono, 1991). Ini bermakna memberikan penghormatan terhadap golongan lain yang mempunyai budaya yang berbeza dari dirinya.

Dari sudut pandangan sarjana yang disoroti menunjukkan bahawa terdapat pelbagai istilah daripada pelbagai sudut iaitu agama, falsafah dan sosial. Perspektif agama adalah satu bidang yang sering 
dibahaskan dan dikembangkan melalui istilah pluralisme ini. Namun dari dimensi pengkaji, pluralisme itu dilihat dari istilah sosiologi. politik plural bagi menimbulkan pancaran elemen di dalam kajian iaitu berlaku kepelbagaian yang wujud di dalam mematangkan demokrasi melalui proses pendemokrasian yang wujud pelbagai elemen dalam politik plural itu sendiri.

Kepelbagaian dalam politik plural itu sebenarnya dapat memecahkan tembok besar elit politik namun dengan hujahan oleh sarjana merupakan satu cabaran kepada elit politik di dalam sesebuah negara. Pluralisme dapat difahami oleh pengkaji di mana elemen toleransi perlu dipupuk oleh kelompok elit politik di dalam mewarnai pendemokrasian kepada yang lebih baik. Toleransi adalah sandaran pengkaji kerana perbahasan sarjana banyak membincangkan mengenai perbezaan, kepelbagaian dan kelainan dalam semua hal termasuk budaya, bahasa, agama, ras, etnik dan lain-lain.

\section{Hasil Kajian dan Perbincangan}

Kajian ini membincangkan tentang pandangan dan pendapat secara umum tentang kesan elitisme dan pluralisme dalam politik negara terutamanya dalam parti UMNO dan koalisinya iaitu Barisan Nasional. Secara keseluruhannya, terdapat 7 orang responden yang bertindak sebagai pemegang taruh membahaskan tentang elitisme dan pluralisme dalam politik Malaysia.

Dapatan kajian mendapati menteri-menteri dari kelompok UMNO/BN mengamalkan sifat yang lebih elitis dan membina legasi politik. Amalan ini membolehkan mereka mendominasi parti itu dan dilihat secara beransur-ansur menguasai aspek nasional (R1 2021; temu bual). Namun begitu ia dinafikan oleh (R6 2021; temu bual) yang menyatakan bahawa amalan elitis dari kelompok keluarga pemimpin politik UMNO/BN hanya bersifat persepsi sahaja. Manakala berdasarkan (R2 2021; temu bual), aspek pemikiran dan ideologi UMNO/BN, juga dilihat telah membina satu 'tembok besi' dengan rakyat Malaysia apabila realiti dari rakyat semakin terputus secara beransur-ansur. Ini dapat dilihat apabila sepanjang penguasaan mereka sebagai parti pemerintah, mereka mempunyai kesukaran akses kepada masyarakat. Ini termasuk kaedah pemberian dana dan bantuan demokrasi yang semakin formal dan berlaku kesukaran dalam aspek bantuan dan pemberian. Amalan ini menjadi semakin formal dan diteruskan di sepanjang pemerintahan UMNO/BN.

Menurut (R2 2021; temu bual) juga model UMNO/BN yang bersifat elitis di bawah pemerintahan Najib Razak pada penggal kedua (2013-2018) dilihat tidak bersesuaian dan menyantuni pluralisme politik Malaysia. Ini meliputi pelbagai sudut seperti kaum, kelas, ideologi politik, dan tuntutan agama. Hukuman yang diberikan kepada rakyat seperti mengenakan cukai baru, peningkatan kos sara hidup, pengangguran di samping menafikan tokoh-tokoh tertentu dan mempamerkan kemewahan di kalangan keluarga pemimpin dilihat sebagai cubaan mempertahankan kuasa rejim pemerintah. Tindakan yang dilakukan seperti dibahaskan dilihat mewujudkan garis pemisah di antara kelas kayangan dan rakyat terbanyak. Ini menyaksikan peranan dan tindakan yang sepatutnya terarah kepada mendengar denyut nadi rakyat bertukar kepada terputus realiti dengan rakyat

Penghujahan yang sederhana juga telah dilontarkan bagi menggambarkan situasi politik yang dikatakan bersifat pluralistik ini. Ungkapan yang terkenal bekas Canselor Empayar Jerman-Prussia, Otto Von Bismarck (1815-1898) iaitu "politics is the art of the possible" merupakan kemungkinan yang berlaku di dalam tampuk kuasa. Menurut (R3 2021; temu bual), kelompok-kelompok tertentu sama ada dari kelompok elit mahu pun kelompok plural mana akan berkuasa jika ianya mendapat sokongan yang lebih banyak. Menurut (R4 2021; temu bual), politik yang lebih elitis dilihat pada era Tunku Abdul hingga ke era Tun Dr. Mahathir Mohamad. Barisan Nasional (BN) dan komponen serta gabungannya mengamalkan politik yang lebih elitis. Ia dapat dilihat di dalam penggubalan dasar-dasar di dalam pemerintahan yang bersifat elitistik iaitu 'top and down' yang membawa kepada dasar-dasar yang menguntungkan rakyat semua kaum.

Manakala menurut (R5 2021; temu bual), terdapat gerakan-gerakan yang bersifat lebih pluralis dengan pelbagai tuntutan terhadap parti pemerintah iaitu UMNO/BN. Gerakan-gerakan ini mendapat perhatian majoriti masyarakat dan memberi keyakinan kepada mereka di dalam beberapa isu yang bersifat tidak 
menyebelahi parti pemerintah. Amalan politik yang elitis UMNO/BN begitu terserlah apabila masih kekal dengan amalan mempertahankan status quo dan bersifat elitistik yang dilakukan oleh rejim tersebut disebabkan sifat parti itu yang telah lama berkuasa dan sudah tentu usaha mengekalkan kuasa berlaku seperti mana kenyataan (R7 2021; temu bual).

Politik di Malaysia sangatlah dipengaruhi oleh elitisme dalam menentukan dasar, pendekatan dan kepimpinan. Ianya termasuk aspek pemilihan individu di dalam menerajui kepimpinan struktur di negeri, pusat mahupun peringkat parti. UMNO dan koalisinya berjaya mempertahankan kuasanya dengan sifat elitisme di sebalik perubahan politik yang lebih pluralistik sifatnya. Ia dianggap pula sebagai satu nilai perdana dan biasa dalam sistem demokrasi ala-Malaysia. Walaupun elemen-elemen tertentu dalam permuafakatan masih lagi wujud seperti perkongsian kuasa antara elit pemerintah, adanya rundingan dan sebagainya namun permuafakatan itu dianggap sebagai formaliti sahaja kerana realitinya, UMNO/BN bertindak secara dalam permuafakatan itu dengan menguatkan pengaruh dan kekuatannya dalam kerajaan. Apabila sifat elitisme itu yang menjadi tunjang dalam mencorakkan segala macam bentuk politik maka ianya akan mempengaruhi politik Malaysia. Ini berlaku sejak dari era Dato Onn pada tahun 1946 lagi sehingga era pasca PRU-14 di mana amalan politik masih kekal dengan amalan tradisionalisme dan neo-feudalisme. Dapat dilihat bahawa elitisme merupakan satu faktor yang dominan di dalam menentukan hala tuju politik di Malaysia. Ini ditambah pula dengan kepintaran UMNO/BN mencanai setiap dasar dan polisi pemerintahan mereka menerusi penaungan politik elit-elit kaum yang kuat serta pengekalan amalan-amalan yang dikonstruksi oleh BN dengan berkesan dalam sosiopolitik, ekonomi dan budaya setiap kaum yang diwakili dalam BN. Penaungan dan politik ini ternyata berjaya memupuk nilai kesetiaan yang tinggi. Ciri-ciri politik baru ini secara perlahan mengikis amalan politik lama yang selama ini dipupuk oleh parti pemerintah dalam mengekalkan kuasa.

Selain itu, gambaran mengenai politik yang berlaku dalam kancah perdebatan di dunia politik ini berkait rapat juga kekeluargaan, kepentingan hidup dan perkauman dan etnik. Berdasarkan identiti kolektif yang menekankan penanda-penanda identiti etnik yang paling menyerlah untuk membezakannya dengan kategori etnik lain (Pue \& Charanjit, 2012). Akibatnya, pendekatan tafsiran autoriti tidak mampu memberikan gambaran kepelbagaian etnik dalam masyarakat yang dinamik lagi pelbagai yang wujud dalam kehidupan harian. Kepelbagaian etnik dalam kehidupan seharian hanya dapat diserlah atau dilihat menerusi satu lagi pendekatan yang lebih mikro iaitu tafsiran harian. Melalui pendekatan ini, identiti etnik digambarkan sebagai 'artikulasi pengalaman peribadi' di mana gambaran tentang siapa diri pelaku sebagai ahli kumpulan etnik, terbit dan dipengaruhi oleh pengalaman yang dilalui mereka dalam kehidupan seharian (Shamsul, 1996).

\section{Kesimpulan}

Pandangan yang lebih luas dikemukakan oleh Dwaine Marvick. Menurut beliau ada dua tradisi akademik tentang elit. Pertama, dalam tradisi yang lebih tua, elit diperlukan sebagai individu khusus yang menjalankan misi historis, memenuhi keperluan mendesak, melahirkan bakat-bakat unggul, atau menampilkan kualiti tersendiri. Elit dipandang sebagai kelompok pencipta tahanan yang kemudian dianuti oleh semua pihak. Kedua, dalam tradisi yang lebih baru, elit dilihat sebagai kelompok, baik kelompok yang menghimpun para pemerintahan atau penguasa di berbagai sektor dan tempat. Pengertian elit dipadankan dengan pemimpin, pembuat keputusan, atau pihak berpengaruh yang selalu menjadi personaliti rujukan dan ikutan. Pada hakikatnya, hanya dengan satu undi boleh menentukan kemenangan atau kekalahan sesebuah parti dalam membentuk kerajaan pada masa akan datang (Ismail Sulaiman, 2016).

Di samping itu, politik ini dipengaruhi oleh elitis yang menjadi kuasa yang secara efektif memonopoli kedudukan-kedudukan penting di dalam masyarakat. Ini dikuatkan oleh Robert Michel (1962) yang memperkenalkan teori yang dikenali sebagai "hukum kuku besi oligarki" menegaskan bahawa di dalam sesebuah organisasi, penguasaan segelintir ke atas yang ramai adalah tidak dapat dielakkan. Sebaliknya, Lasswell (1952) berpendapat bahawa elit sebenarnya bersifat pluralistik. Personaliti tersebar, pemimpin silih berganti pada setiap tahap fungsi dalam proses pembuatan keputusan, dan peranannya pun boleh naik turun tergantung keadaan. Bagi Lasswell (1952), situasi itu yang lebih penting, dalam situasi 
peranan elit tidak terlalu menonjol dan status elit boleh ada kepada siapa saja yang mempunyai peranan penting. Hasil daripada kajian mendapati di sebalik transformasi politik yang lebih pluralistik kini mendapati kehadiran politik pluralisme yang lebih ketara lewat ini melahirkan proses demokrasi yang lebih baik. Landskap politik Malaysia juga berubah apabila kewujudan pluralisme baru telah melahirkan politik yang berbeza yang bersifat baharu. Nilai inilah yang melahirkan politik yang lebih matang dan meningkatkan nilai demokrasi itu sendiri. Amalan pengekalan politik elitisme oleh UMNO/BN seolaholah dinafikan oleh politik pluralisme Pakatan Harapan. Ini dapat dilihat apabila pluralisme menyumbang kepada perubahan kerajaan secara demokratik dalam PRU-14. UMNO/BN yang memerintah selama enam dekad telah tewas oleh kelompok politik yang lebih pluralis sifatnya hasil daripada resepsi terbaik iaitu penyatuan parti penentang bersama dengan masyarakat sivil yang kelihatan lebih progresif lewat dua dekad ini.

\section{Penghargaan}

Penulisan ini sebahagiannya dibiayai oleh Universiti Kebangsaan Malaysia melalui Tabung Agihan Penyelidikan (TAP-K016199)

\section{Rujukan}

Abdul Razaq Ahmad, Mohd Mahzan Awang \& Jamil Ahmad. (2017). Aspirasi terhadap kepimpinan politik negara. Malaysian Journal of Youth Studies, 16, 19-47.

Agus Susilo \& Isbandiyah (2018). Politik Etis dan Pengaruhnya bagi Lahirnya Pergerakan Bangsa Indonesia. Jurnal HISTORIA, 6(2).

Bachrach, P., \& Baratz, M., (1977). Power and Poverty: Theory and Practice. London: Oxford University Press.

Badrul Azmier Mohamed @ Bakar. (2008). Lima Puluh Tahun Dominasi Barisan Nasional Dalam Politik Malaysia: Suatu Analisis dlm. Worran Hj. Kabul, Shireen Haron, Mat Zin Mat Kib dan Abdul Kadir Rosline Prosiding Seminar Politik Malaysia Landskap Politik Malaysia Pasca Pilihan Raya Ke-12. Shah Alam: UPENA.

Bottomore, T. (1996). Elite dan Masyarakat. Jakarta: Akbar Tanjung Institute

Crouch, H. (1996). Goverment and Society in Malaysia. St. Leonard, NSW: Allen \& Unwin

Gerald O' Collins \& Edward G. Farrugia. (1996). Kamus Teologi. Yogyakarta: Kanisius. hlm. 13.

Field dan Higley dalam Adam Kuper \& Jessica Kuper. (2000). Ensiklopedia Ilmu-Ilmu Sosial. Jakarta Raja Grafindo Persada, hlm 285

Flathman, Richard E. (2007). Pluralism and Liberal Democracy. Florida State University.

Haikal Mujahid. (2011) (Etika Dan Kekuasaan): Pemikiran Niccolo Machiavelli Atas Etika Dan Kekuasaan Dalam Ranah Politik. Universitas Islam Negeri Syarif Hidayatullah, Jakarta, Indonesia (UIN).

Hanapi Dollah. (1986). Asimilasi budaya: kajian kes komuniti Cina di Kelantan. Bangi: Penerbit Universiti Kebangsaan Malaysia.

Hariati Azizan. (2011). Ignorance is not bliss. The Star, 23 Januari.

Hirschman, C. (1987). The meaning and measurement of ethnicity in Malaysia: an analysis of census classifications. Journal of Asian Studies, 46(3), 555- 582

Holst, F. (2012). Ethnicization and identity construction in Malaysia. London: Routledge.

Ismail Sulaiman (2016). Buta Politik Faktor Survival, Berita Harian, Oktober, 2015.

Jamaie Haji Hamil. (2003). Kepimpinan Politik: Pola Kepimpinan Politik UMNO. Jurnal Akademika, 62(7), 17-39.

Jesudason, J. V. (1996). Statist Democracy and the Limit to Civil Society in Malaysia. Journal of Commonwealth and Comparative Politics, 33(3), 335-356.

Karppinen, Kari. (2007). Making a difference to media pluralism:a critique of the pluralistic consensus in European media policy. In Reclaiming the Media: Communication Rights and Democratic Media Roles, by Bart Cammaerts and Nico Carpentier, 9-30. Bristol: Intellect Ltd.

Keller (1995). Istilah Elit Sebenarnya, Bab II, Kajian Pustaka. Elit. https://adoc.pub/bab-ii-kajianpustaka-elitkeller-199531-istilah-elit-sebenar.html 
Lerner, D. (1958). The Passing of Traditional Society. New York: The Free Press.

Lipset, Solari dalam J.W. Scoorl. (1982). Modenisasi, Penghantar Sosiologi Pembangunan NegaraNegara Sedang Berkembang. Jakarta:Gramedia, hlm 128.

Majid. S (2010). Reaksi Model Ekonomi Baru. Berita Harian, 31 Mac, hlm. 8. [ Akses 30 September 2021]

Mashelayati Mohd Razali (2020). Dinamisme masyarakat Malaysia: Esei sumbangsih untuk Prof. Dr. Kanthasamy A/L Nallusamy (pp.163-174) Publisher: Penerbit Universiti Pendidikan Sultan Idris

Mazlan Ali, Zulkanain Abdul Rahman \& Amer Saifude Ghazali. (2012). Perkembangan Politik Kuala Lumpur, 1969-1999. Dlm. Demokrasi dan Pilihan Raya. Jurnal Pusat Kajian Demokrasi dan Pilihan Raya Universiti Malaya (UMCEDEL).

Miles, R., \& Brown, M. (2003). Racism. New York: Routledge.

Moeliono, Anton M. (1991). Kamus Besar Bahasa Indonesia. Jakarta: Balai Pustaka.

Mohd Adzid Mohd Isa (2015). Bab 3: Polemik Pasca Liberal-Pluralisme di Indonesia dan Malaysia, Pasca Modenisasi dan kelangsungan Islam.Majlis Agama Islam Selangor, MAIS).

Mohd Yusof Kasim \& Azlan Ahmad (2002). Politik Baru Dalam Pilihanraya Umum. Bangi: Penerbit Universiti Kebangsaan Malaysia.

Mohd Zuwairi Mat Saad, Normah Mustapha, Abdul Latif Ahmad \& Badrul Redzuan Abu Hassan. (2016). Sumber berita bingkai pilihan raya: Transisi, pemilihan dan autoriti. Jurnal Komunikasi, 32(1), 535-550.

Mohd. Ghazali Abdullah. (2003). Keunikan budaya Kelantan dalam perpaduan kaum Cina, Melayu dan Siam dari perspektif bahasa dan budaya. Dlm. Peradaban Melayu Timur Laut, disunting oleh A. Aziz Deraman, 76-89. Kuala Lumpur: Dewan Bahasa dan Pustaka.

Muhamad Nadzri \& Jamaie. (2018). Politik, Pengundi dan Faktor Melayu/Bumiputera: Analisis Terhadap Kegagalan Barisan Nasional Dalam PRU 2018. Jebat: Malaysian Journal of History, Politics and Strategic Studies, 45(20), 386-408.

Mujibu Abd Muis. (2009). Politik Permuafakatan: Satu Analisa Terhadap Amalan Politik di Negaranegara Bermasyarakat Majmuk. Voice of Academia: ! e Academic Series, 4(2).

Nordin Sakke, Ramli Dolah \& Mohammad Tahir Mapa. (2009). Penghijrahan dan Perkembangan Masyarakat Bugis di Sabah. Dlm. Asmiaty Amat (Ed.). Bugis Sabah. Siri Etnik Sabah. Kuala Lumpur: Penerbit ITBM-UMS.

Pue Giok Hun \& Charanjit Kaur (2014). Identiti Etnik Minoriti di Malaysia: Antara Realiti Sosial Tafsiran Autoriti dan Tafsiran Harian, Akademika 84(1\&2) 2014:57-70

Ramli Dollah etl.al (2018). Peranan Belia Dan Pru-14 di Sabah: Kajian Kes Di P.188 Silam, Jurnal Kinabalu Edisi Khas, 319-349.

Santrock, J. W. (2003). Psychology. USA: McGraw-Hill Education, 430-435; Robert S. Feidman, Essentials of Understanding Psychology, Fifth Edition, (USA: McGraw Hill Higher Education, 254-255.

Shamsul, A. B. (1996). Construction and transformation of a social identity: Malayness and Bumiputeraness re-examined. Journal of Asian and African studies, 52.

Shamsul, A. B. (2001). 'Malay' and 'Malayness' in Malaysia reconsidered: a critical review. Communal/Plural, 9(1): 69-80.

Shamsul, A. B. (2006). Identity contestation in Malaysia: a comparative commentary on 'Malayness' and 'Chineseness'. Dlm. Inter-ethnic relations in Malaysia: selected readings, disunting oleh Jayum A. Jawan \& Zaid Ahmad, 118-139. Serdang: Universiti Putra Malaysia Press.

Shamsul, A. B. (2014). Perpaduan, kesepaduan dan penyatupaduan: satu negara, satu kata akar, tiga konsep keramat. Ucapan dasar pada Persidangan Pemantapan Citra Kenegaraan: Perkongsian Pengalaman di Universiti Kebangsaan Malaysia, 19-21 Januari, Bangi.

Suhana Saad (2012) Re-building the concept of nation building in Malaysia. Asian Social Science, 8, $115-123$

Suhana Saad et al. (2012). Krisis politik Melayu dan pembinaan negara bangsa, GEOGRAFIA OnlineTM Malaysia Journal of Society and Space, 8(9), 39 - 45.

Syed Husin Ali (2012) Ethnic and social cohesion, temubual pada 24 Jan.

Wade, G. 2014. The Origins and Evolution of Ethnocracy in Malaysia. The Asia-Pacific Journal, 7(7).

Zaini Othman. (2006). Demokrasi di Negara Sedang Membangun: Pengalaman Asia Tenggara. Dlm. Ghazali Mayudin, Jamaie Hamil, Sity Daud \& Zaini Othman (pnyt.) Demokrasi Kepimpinan dan Keselamatan Dalam Politik Malaysia, hlm. 26- 49. Bangi: Penerbit UKM. 